(Y) were included to establish the following regression equation: $\mathrm{Y}=-130.986+34.505 \mathrm{X}\left(\mathrm{R}^{2}=0.556, \mathrm{p}<0.05\right)$.

Conclusions Stem cell transplantation with CD34-targeted microbubble may increase therapeutic effects via angiogenesis in AMI rabbits, $\mathrm{PQ}$ probably provides some value in invasive evaluation of angiogenesis after stem cell transplantation.

\section{[gw22-e0081] EVALUATION OF ANGIOGENESIS AFTER STEM CELL TRANSPLANTATION USING COLOUR- ENCODED PARAMETRIC QUANTIFICATION WITH TARGETED MICROBUBBLES IN RABBITS WITH MYOCARDIAL INFARCTION}

Mu Yuming1', Ca Guiqiu1, Li Yanhong1, Zeng Qianqian', Wang Chunmei', Jiang $\mathrm{TaO}^{2}{ }^{1}$ Department Of Echocardiograph, The First Affiliated Hospital Of Xinjiang Medical University, Xinjiang, China; ${ }^{2}$ Animal Center Of The First Affiliated Hospital Of Xinjiang Medical University, Xinjiang, China

\subsection{6/heartjnl-2011-300867.140}

Objective To Investigate the application of parametric quantification (PQ) with targeted microbubbles on angiogenesis after Stem Cell Transplantation in rabbits with Myocardial Infarction.

Methods Prepare a CD34-targeted microbubble. Randomly assigned eighty (80) New Zealand white rabbits into 1 Control Group and 3 Experimental Groups: Single Transplantation Group (T Group), Transplantation with common microbubble Group ( $\mathrm{T}+\mathrm{C}$ Group), and Transplantation with CD34-targeted microbubble ( $\mathrm{T}+\mathrm{T}$ Group); the acute myocardial infarction (AMI) model was established by ligating the left anterior descend branch of coronary artery. Each rabbit in the experimental groups received autologous stem cell transplantation, and rabbits in the $\mathrm{T}+\mathrm{C}$ Group and the $\mathrm{T}+\mathrm{T}$ Group as well as control Group were subjected to Myocardial contrast echocardiography (MCE), then compare myocardial perfusion parameters ( $A, \beta$ and $A \times \beta$ values) pre- and $3 d$ post-ligation and 4 weeks after stem cell transplantation. The animals were sacrificed to determine microvessel density (MVD) by CD34 antibody immunohistochemistry.

Results (1) Compared to before stem cell transplantation and the Control Group, the perfusion scores of $\mathrm{T}+\mathrm{C}$ Group and $\mathrm{T}+\mathrm{T}$ Group were increased; (2) In 4 weeks after stem cell transplantation, $A, \beta$ and $A \times \beta$ values of $\mathrm{T}+\mathrm{C}$ Group (2.78 \pm 0.74 vs $2.04 \pm 0.96,0.91 \pm 0.24$ vs $0.20 \pm 0.17,2.54 \pm 0.24$ vs $0.29 \pm 0.16)$ and T+T Group $(2.93 \pm 0.50$ vs $2.13 \pm 0.68,1.17 \pm 0.24$ vs $0.22 \pm 0.16$, $5.69 \pm 0.39$ vs $0.36 \pm 0.23)$ were higher than those prior to stem cell transplantation $(p<0.01)$, moreover, the changes in those indexes in the $\mathrm{T}+\mathrm{T}$ Group were more significant than those in the T+C Group and Control Group ( $p<0.05)$; (3) MVDs after stem cell transplantation in the three experimental groups were higher than those of the Control Group (10.02 \pm 8.12$)$ $(\mathrm{p}<0.01)$, especially MVDs in the T+T Group (63.93 \pm 15.89$)$ and the $\mathrm{T}+\mathrm{C}$ Group $(42.18 \pm 13.54)$ were significantly higher than in the T Group (28.61 \pm 11.57$)(\mathrm{p}<0.05)$; (4) The myocardial perfusion parameters in each of the experimental groups were subjected to correlation and regression analyses with MVD. $A \times \beta$ value in the $\mathrm{T}+\mathrm{C}$ Group was correlated with MVD ( $\mathrm{r}=0.658$, $\mathrm{p}<0.05) ; \beta$ and $A \times \beta$ value in the $\mathrm{T}+\mathrm{T}$ Group were correlated with MVD ( $r=0.620,0.859, p<0.05)$; $A \times \beta$ value $(X)$ and MVD 